\title{
DÜBLIN
}

Technological University Dublin

ARROW@TU Dublin

Articles

School of Chemical and Pharmaceutical

Sciences

2018

\section{Encapsulation of Lead in Rice Phytoliths as a Possible Pollutant Source in Paddy Soils}

Tu N. Nguyen

Faculty of Environmental Sciences, VNU University of Science, Vietnam National University, Hanoi, Vietnam

Minh N. Nguyen

Faculty of Environmental Sciences, VNU University of Science, Vietnam National University, Hanoi, Vietnam

Mary McNamara

Technological University Dublin, Ireland, Mary.McNamara@tudublin.ie

See next page for additional authors

Follow this and additional works at: https://arrow.tudublin.ie/scschcpsart

\section{Recommended Citation}

Nguyen, T.N. et al (2019)Encapsulation of lead in rice phytoliths as a possible pollutant source in paddy soils, Environmental and Experimental Botany, Volume 162, June 2019, Pages 58-66. DOI: 10.1016/ j.envexpbot.2019.02.009

This Article is brought to you for free and open access by the School of Chemical and Pharmaceutical Sciences at ARROW@TU Dublin. It has been accepted for inclusion in Articles by an authorized administrator of ARROW@TU Dublin. For more information, please contact arrow.admin@tudublin.ie, aisling.coyne@tudublin.ie, gerard.connolly@tudublin.ie.

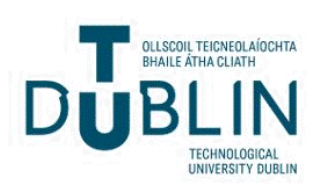




\section{Authors}

Tu N. Nguyen, Minh N. Nguyen, Mary McNamara, Stefan Dultz, Andrew Meharg, and Van T. Nguyen

This article is available at ARROW@TU Dublin: https://arrow.tudublin.ie/scschcpsart/90 


\title{
Encapsulation of lead in rice phytoliths as a possible pollutant source in paddy soils
}

\author{
Tu N. Nguyen ${ }^{\mathrm{a}, \mathrm{b}, \mathrm{c}}$, Minh N. Nguyen ${ }^{\mathrm{a},{ }^{*}}$, Mary McNamara ${ }^{\mathrm{c}}$, Stefan Dultz ${ }^{\mathrm{d}}$, Andrew Meharg ${ }^{\mathrm{e}}$, \\ Van T. Nguyen ${ }^{\mathrm{a}}$ \\ ${ }^{a}$ Faculty of Environmental Sciences, VNU University of Science, Vietnam National University, Hanoi (VNU) 334-Nguyen Trai, Thanh Xuan, Hanoi, Viet Nam \\ ${ }^{\mathrm{b}}$ Faculty of Environment, Vietnam National University of Agriculture, Trau Quy, Gia Lam, Hanoi, Viet Nam \\ ${ }^{\mathrm{c}}$ Dublin Institute of Technology, Focas Research Institute, Kevin Street, Dublin 8, Ireland \\ ${ }^{\mathrm{d}}$ Institute of Soil Science, Leibniz Universität Hannover, Herrenhäuser Straße 2, 30419, Hannover, Germany \\ 'Institute for Global Food Security, Queen's University Belfast, David Keir Building, Malone Road, BT9 5BN, NIR, UK
}

\section{A B S T R A C T}

Due to its serious health risks, lead $(\mathrm{Pb})$ in rice, specifically its uptake, translocation, and accumulation mechanisms and its toxic effects have been studied intensively in recent years. However, it remains unclear about the role of phytolith, a siliceous structure in rice plants, in the storage and release kinetics of $\mathrm{Pb}$ in rice. This study aims at elucidating a possible encapsulation of $\mathrm{Pb}$ in the phytolith structure (phytPb), and identifying whether or not phytPb provides a source of $\mathrm{Pb}$ in soil, when returned to the field with the rice straw or in a related processed product such as ash from on-site burning. To date there has not been any specific work targeted at the determination of phytolithassociated heavy metals in general and phyt $\mathrm{Pb}$ in particular, and therefore this possible source of $\mathrm{Pb}$ in soils may have been overlooked. Phytoliths were included in a study of rice paddy soil and rice straw to demonstrate accumulation of phytolith and its associated phytPb in agricultural soils of the Red River Delta (Vietnam). The total content of Pb in rice straw samples was found to be up to $118 \mathrm{mg} \mathrm{kg}^{-1}$, and this $\mathrm{Pb}$ sink can be cycled to serve as a new $\mathrm{Pb}$ source in soils. The fate of $\mathrm{Pb}$ in rice straw might be directly related to open burning activity (a common practice in the Red River Delta), in which volatilization or sub-compartmentation in slagged phytolith appeared as controlled factors. This is supported by the findings from batch experiments for rice straw ash samples, in which release of $\mathrm{Pb}$ was low and a portion of $\mathrm{Pb}$ in rice straw were found to associate with phytolith structural organic matter. We also observed the presence of phytPb in "aged" phytolith fragments which had accumulated in the paddy field soil. However this $\mathrm{Pb}$ pool was relatively low (from 7.8 to $34 \mathrm{~kg} \mathrm{ha}^{-1}$ ) relative to other soil $\mathrm{Pb}$ fractions. As the thermal treatments of $\mathrm{Pb}$-tainted rice straw resulted in losses of $\mathrm{Pb}$ via volatilization, open-field burning practices for $\mathrm{Pb}$ contaminated rice straw is suggested as an environmental risk

\section{Introduction}

Contamination of agricultural soils by lead $(\mathrm{Pb})$ is a serious environmental threat, since $\mathrm{Pb}$ can enter the food chain and cause many serious health problems in humans (Fakhri et al., 2018; Koedrith and Seo, 2011; Nutescu et al., 2016), particularly affecting the central nervous system of children (Wasserman et al., 1997). It has been widely reported for many agricultural regions that anthropogenic activities e.g. mining or recycling activities have led to excessive accumulation of Pb in rice (Oryza sativa L.) (Fu et al., 2008; Li et al., 2014a; Nguyen et al., 2009a; Yu et al., 2016). Pb in soil solutions can be assimilated within plants and transported, in a stepwise fashion, from root to stem, stem to leaves and leaves to grain (Udousoro et al., 2013). Genotypic variation might be a primary factor for Pb translocation as reported by Liu et al. (2013); Zeng et al. (2008), while the structure and properties of the membrane transport system are likely to further affect $\mathrm{Pb}$ localization within rice plants (Uraguchi et al., 2009). In rice, a so-called phytolith structure, formed by precipitation of silicon (Si) throughout inter- and intracellular spaces, has been proposed as a "trap" for organic matter (Guo et al., 2015; Li et al., 2013; Nguyen et al., 2014; Song et al., 2015) and nutrients e.g. K, P, Fe (Li et al., 2014b; Nguyen et al., 2015; Trinh et al., 2017). It can, therefore, be hypothesized that this phytolith structure can similarly affect translocation of $\mathrm{Pb}$ in rice or even trap $\mathrm{Pb}$ from transport sap (hereinafter referred to as phytolithassociated $\mathrm{Pb}$ "phytPb"). The observation that in silicate glasses $\mathrm{Pb}$ is inserted into the vitreous structure as $\mathrm{Si}-\mathrm{O}-\mathrm{Pb}$ bonds (Angeli et al., 2016), also suggests the possible presence of $\mathrm{Pb}$ in the structure of phytoliths. However, there is little information available on whether or not $\mathrm{Pb}$ is compartmentalized in phytoliths. In rice plants, Si can be attached to cell walls along the longitudinal vascular bundles, veins or fibers of the plant (Botha, 2013; Trinh et al., 2017) and as a consequence, Si forms a coating layer, covering the internal and external surfaces of the vascular system. Excessive precipitation and polymerization of Si is likely to create a high-porosity system with various size holes (Nguyen et al., 
2014) including micropores (Mohamad Remli et al., 2014), in which organic matter and other substances such as $\mathrm{Pb}$ can be embedded. However, little information is available on the role of this siliceous phytolith structure in encapsulating $\mathrm{Pb}$ from transport sap in rice plants and the bioavailability of this $\mathrm{Pb}$ pool when rice straw is recycled back to the field.

Accumulation of phytolith in paddy field soils via recycling of rice straw has been reported in a number of recent studies (Klotzbücher et al., 2016; Kögel-Knabner et al., 2010; Nguyen et al., 2016; Wang et al., 2015). Phytolith in soil was intensively studied as a bioavailable source of $\mathrm{Si}$, which is crucial for Si-demanding crops such as rice, wheat, maize and sugarcane (Haynes, 2014; Sommer et al., 2013). Yet, there is a lack of information regarding the fate of other phytolith-accompanied substances (e.g. encapsulated inorganic ions), except organic carbon in phytolith (phytC), which is widely studied because of its importance to carbon sequestration (Parr and Sullivan, 2005; Qi et al., 2017; Ru et al., 2018; Song et al., 2015; Song et al., 2016). In general, it can be assumed that the fate of phytolith-accompanied substances such as phytC and phytPb, might depend on the destruction of phytolith, particularly through dissolution. The dissolution process is supported by a hydrolysis reaction, in which nucleophilic attack of water molecules on the $\mathrm{Si}$ atoms of the $\mathrm{Si}-\mathrm{O}-\mathrm{Si}$ and $\mathrm{Si}-\mathrm{OH}$ groups can result in destruction of the phytolith surface (Dove and Crerar, 1990). This destruction can lead to release of $\mathrm{K}$ and $\mathrm{P}$ occluded within the phytolith structure, as reported by Nguyen et al. (2015) and Trinh et al. (2017), and suggests that a similar situation is possible for phytPb.

Until now, phytPb in croplands has not been studied or reported as a sink and source of $\mathrm{Pb}$, which can potentially affect soil and crop quality and human health. In this study, physical separation of phytolith using heavy liquid and chemical extraction of phytPb for soil samples from paddy fields located near $\mathrm{Pb}$ recycling facilities in the Red River Delta in Vietnam was conducted to provide evidence for possible accumulation of phytolith and its associated phytPb in agricultural soils. Burning is a common practice to deal with rice-straw residues in many rice-based countries. Here we also investigated the dissolution properties of phyt $\mathrm{Pb}$ of a $\mathrm{Pb}$-tainted rice-straw sample obtained from thermal treatment. This will help to elucidate the fate of $\mathrm{Pb}$ in rice paddies, so as to develop new practices for the alleviation of the impact of phytPb. To date there have been no reports of the determination of phytolith-associated heavy metals, including phytPb, suggesting further work on phytPb is necessary.

\section{Materials and methods}

\subsection{Study site and sample processing}

The soil samples used in this study derive from a paddy field in the vicinity of a handicraft village which locates at Dong Mai commune in the central part of the Red River Delta in Viet Nam. This soil, as a result of air-deposition and sewage sludge usage, has been contaminated by $\mathrm{Pb}$ from lead-acid battery recycling carried out in the village for the past few decades (Fujimori et al., 2016). After harvesting, rice straw is either directly incorporated into the soil or returned to the soil following burning, and thus the rice straw-derived phytolith pool, as well as $\mathrm{Pb}$ in the soil, is sustained in the local rice cropping system. Soil samples were collected from 10 small-scale paddy fields surrounding the village in October 2017, immediately after harvest time. In each field, the soil was sampled from the 0-20 cm surface layer, at 3 different sites and the samples from each field were homogenized and combined. The soil samples were then air-dried and passed through a $2.0-\mathrm{mm}$ sieve and the $<2-\mathrm{mm}$ fraction was used for the experiments. In another campaign to study pathological evidence of rice plants grown on Pb-polluted areas, $\mathrm{Pb}$-polluted soil from the Dong Mai village was used for pot experiments in a greenhouse to avoid ongoing contamination. Rice straw harvested from the pot experiments was used to characterize the phytolith and phytPb.

Since on-site burning is the most typical practice to treat rice-straw residues, and burning is an exothermic process depending on ambient conditions and manner of handling, such as scattered on fields or piled up as stacks, we treated the straw samples from the pot experiments over a range of temperatures from 400 to $1000{ }^{\circ} \mathrm{C}$ in a furnace for $2 \mathrm{~h}$ and the resultant ash was homogenized to a fine powder $(<1.0-\mathrm{mm})$. To avoid strong exothermic reactions during this ashing process, the weight of each sample was limited to $5 \mathrm{~g}$. 


\subsection{Rice plant analysis}

Synchrotron-based X-ray Tomographic Microscopy (SRXTM) was conducted to visualize the structure and the vascular bundles of the dried leaf of a rice plant from the pot experiments. The SRXTM were performed at the TOMCAT beamline, Swiss Light Source, Paul-Scherrer Institute, Switzerland. Sample density, deduced from a grayscale (1-255) of the tomographical data, allows identification of different phases in the phytolith structure. A gray value of 1 represents very low densities, such as air, while a gray value of 255 is attributed to very dense materials, such as silicarich phases. The latter are coloured yellow in the 3D segmentation and visualization process, while intermediate gray levels between 50 and 200, which are characteristic of organic matter, are represented in violet.

Rice straw samples obtained from heat-treatment at $400{ }^{\circ} \mathrm{C}$ to $1000{ }^{\circ} \mathrm{C}$ and products were characterized using powder X-ray diffraction (Bruker AXS D5005, Germany) and SEM-EDS (FESEM S-4800 Hitachi Co., Tokyo, Japan). The reactivity of phytolith is strictly related to changes in surficial properties and, in particular, loss of reactive surface sites (Loucaides et al., 2010). Therefore, surface charge, a key electrochemical parameter of the solid-liquid interface representing ionization, and ion adsorption of surface functional groups (Walther, 1996), might provide important information on dissolution properties of phytolith and phytPb. Surface charge was quantified by polyelectrolyte titration in a particle-charge detector (PCD 05, Mütek, Herrsching, Germany). The chemical composition of the straw ash was analysed by a Particle-Induced X-Ray Emission system (PIXE), using the proton beam of a Tandem accelerator (5SDH-2 Pelletron National Electrostatics Corporation, USA, at the VNU University of Science, Vietnam National University, Hanoi).

The solubility of $\mathrm{Pb}$ from straw ash was determined by using four different extraction/digestion systems, including deionized ( $\mathrm{DI}$ ) water for free $\mathrm{Pb}, 30 \% \mathrm{H}_{2} \mathrm{O} 2$ for organically bound $\mathrm{Pb}$, aqua regia $(3: 1 \mathrm{HCl} / \mathrm{HNO} 3$ ) for the pseudo-total content of $\mathrm{Pb}$ (hereby referred to the residual fractions, ISO 11466 (1995) and 1\% $\mathrm{Na2} \mathrm{CO}_{3}$ for phytPb. The extracted amounts are compared with the total Pb content derived from PIXE. Each $50 \mathrm{mg}$ sample of the ash was mixed with 50 $\mathrm{mL}$ of the prepared solvent and then processed as follows. For suspensions in DI water, $1 \mathrm{M} \mathrm{HCl}$ was added dropwise to adjust the $\mathrm{pH}$ to 5 , before bringing the total volume to $50 \mathrm{~mL}$. The suspensions were then gently shaken and allowed to stand for $24 \mathrm{~h}$ at room temperature. The suspensions in $\mathrm{H}_{2} \mathrm{O}_{2}$ were shaken and kept in a water bath at $80{ }^{\circ} \mathrm{C}$ for $24 \mathrm{~h}$. The suspensions in aqua regia were prepared in a digestion block and heated over $1 \mathrm{~h}$ at $300^{\circ} \mathrm{C}$ and allowed to cool to room temperature. The $1 \% \mathrm{Na} 2 \mathrm{CO} 3$ suspensions were treated in a water bath at $85^{\circ} \mathrm{C}$ for $3 \mathrm{~h}$. All experiments were terminated by filtration of the suspension through a cellulose acetate filter with a pore size of $0.45 \mu \mathrm{m}$. Soluble ions ( $\mathrm{Si}, \mathrm{Pb}$ ) were determined using an ICP-OES (PE $7300 \mathrm{~V}$-ICP, Perkin Elmer). All experiments were performed in triplicate.

\subsection{Soil analysis}

\section{Determination of chemical composition:}

Soil samples were examined by the PIXE method so as to determine chemical composition. Other physio-chemical properties of the soil samples, such as $\mathrm{pH}$ by a pH meter (Toledo, FE20, Switzerland), electro-conductivity (EC) using an EC meter (AD3000, ADWA, Szeged, Hungary), texture using sedimentation method, and organic carbon (OC) content using $\mathrm{K} 2 \mathrm{Cr} 2 \mathrm{O} 7$ wet-oxidation method, were also determined to ascertain how they may relate to phytPb.

\section{Separation of phytoliths from soil and determination of soil phytPb:}

Phytoliths were physically separated from soil samples by using heavy liquid, according to the procedure of Alexandre et al. (1997). Since carbonate, organic matter and clays can interfere with the extraction (Meunier et al., 2014), pre-treatments were conducted as follows. $5 \mathrm{~g}$ of soil samples were subsequently treated with $30 \mathrm{~mL}$ of $1 \mathrm{M}$ $\mathrm{HCl}$ to remove carbonates, with $100 \mathrm{~mL}$ of $30 \% \mathrm{H}_{2} \mathrm{O} 2$ in a water bath at $80{ }^{\circ} \mathrm{C}$ for $10 \mathrm{~h}$ to remove organic matter, and then with $2 \mathrm{~g}$ of sodium dithionite and $10 \mathrm{~mL}$ of DI water in a water bath at $80^{\circ} \mathrm{C}$ for $8 \mathrm{~h}$ to remove Fe oxides. After each treatment step, the filtrates were removed by centrifugation and decantation. The clay fraction was removed by sedimentation and remaining solids containing silt, sand and phytoliths were then dried at $60^{\circ} \mathrm{C}$ for $12 \mathrm{~h}$. Phytolith particles were separated from silt and sand fractions using a cadmium iodide solution at a density of $2.35 \mathrm{~g} \mathrm{~cm}^{-3}$, on which they floated after centrifugation. The phytolith particles were dried and then mounted on thin laminated glass 
for micromorphological analysis and analysis of chemical composition by scanning electron microscopy coupled with energy-dispersive X-ray spectrometry (EDS) (FESEM S-4800, Hitachi Co., Tokyo, Japan). PhytPb was extracted from the phytoliths by using aqua regia solution $\left(\mathrm{HCl}: \mathrm{HNO}_{3}\right)$ in a digestion block. Dissolved $\mathrm{Pb}$ was determined with an ICP-OES (PE 7300 V-ICP, Perkin Elmer).

\section{Fractionation of the phytPb pool:}

To date there has been no report of a method targeted at fractionation of the phytPb pool in soil. Therefore, soil $\mathrm{Pb}$ was fractionated into five fractions, F1-5, by modification of the method of Tessier et al. (1979). Each $2 \mathrm{~g}$ of the soil sample was placed in a polycarbonate centrifuge tube and the following extractions were performed sequentially. $\mathrm{F} 1$ (exchangeable $\mathrm{Pb}$ ) was obtained by extraction with $20 \mathrm{~mL}$ of $1 \mathrm{M} \mathrm{NH} 4 \mathrm{OAc}$ at $\mathrm{pH} 7 \mathrm{for} 2 \mathrm{~h}$ at room temperature. F2 (specifically sorbed and carbonate-bound $\mathrm{Pb}$ ) was obtained by extraction of the residue from $\mathrm{F} 1$, with $20 \mathrm{~mL}$ of $1 \mathrm{M}$ $\mathrm{NH} 4 \mathrm{OAc}$ at $\mathrm{pH} 5$ for $2 \mathrm{~h}$ at room temperature. $\mathrm{F} 3$ (Fe or Mn oxide-bound $\mathrm{Pb}$ ) was obtained by extraction of the residue from $\mathrm{F} 2$ with $20 \mathrm{~mL}$ of $0.04 \mathrm{M} \mathrm{NH} 2 \mathrm{OH} . \mathrm{HCl}$ in $25 \% \mathrm{HOAc}$ for $6 \mathrm{~h}$ in a water bath at $60{ }^{\circ} \mathrm{C}$. F4 (organically complexed $\mathrm{Pb}$ ) was obtained by extraction of the residue from $\mathrm{F} 3$ with $15 \mathrm{~mL}$ of $30 \% \mathrm{H} 2 \mathrm{O} 2$ at pH 2 for $5.5 \mathrm{~h}$ in a water bath at $80^{\circ} \mathrm{C}$. F5 (residual $\mathrm{Pb}$ ) was obtained after cooling the residue from $\mathrm{F} 4$, by extraction with $5 \mathrm{~mL}$ of $3.2 \mathrm{M} \mathrm{NH} 4 \mathrm{OAc}$ in $20 \% \mathrm{HNO} 3$ for $0.5 \mathrm{~h}$. Dissolved Pb obtained from the sequential extraction was quantified using the ICP-OES (PE 7300 V-ICP, Perkin Elmer). The soil sample was extracted with the sequential extraction described above and, in other experiments, with $0.01 \mathrm{M} \mathrm{CaCl}_{2}$ (solid: solution ratio of 1:20 for $2 \mathrm{~h}$ ) for quantification of bio-available $\mathrm{Pb}$.

\section{Statistical analysis:}

Principal component analysis (PCA) and Pearson's test, which were executed using Excel with the XLSTAT add- on and SPSS 20.0 software respectively, allowing us to evaluate differences in quantitative characteristics and correlations between phyt $\mathrm{Pb}$ and other $\mathrm{Pb}$ fractions.

\section{Results}

\subsection{Transformation of rice-straw phytolith under thermal treatment}

An image of the phytolith structure in a rice leaf, obtained using Synchrotron-based X-ray Tomographic Microscopy (SRXTM), is shown in Fig. 1a.

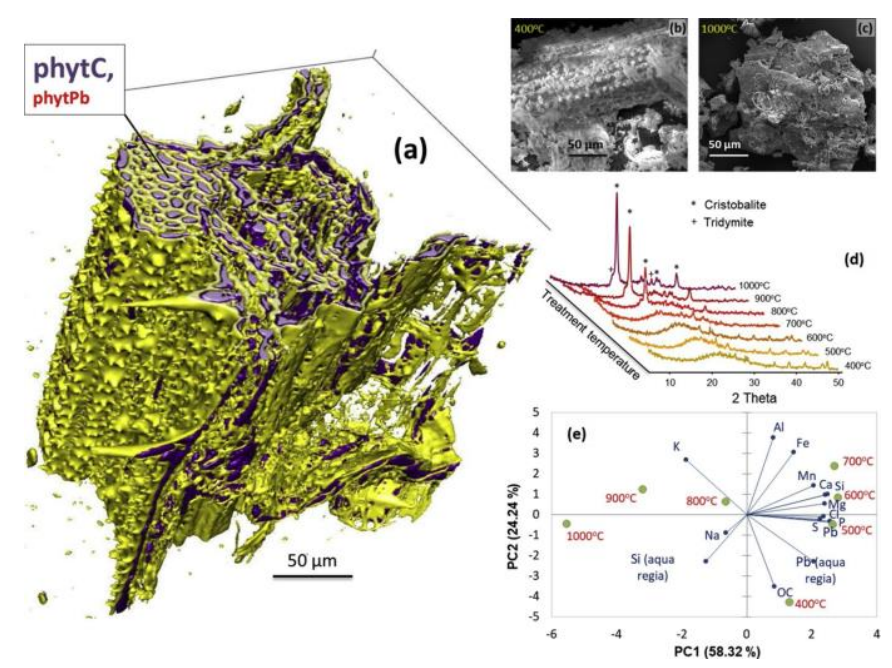

Fig. 1. Images of rice straw where (a) shows a three-dimensional image of a dried leaf obtained from Synchrotronbased X-ray Tomographic Microscopy (SRXTM) with the silicified phytolith structure in yellow (appearing in gray in black and white) and holes, possibly containing organic matter and $\mathrm{Pb}$, shown in violet (appearing in dark gray in black and white), (b) and (c) show SEM images of rice straw samples following thermal treatment at $400{ }^{\circ} \mathrm{C}$ and 1000 ${ }^{\circ} \mathrm{C}$ respectively, (d) shows XRD patterns of rice-straw samples treated at different temperatures, and (e) shows score plots of PC1 versus PC2 indicating the differentiation of Pb forms and other elements in the ashed samples (For 
interpretation of the references to colour in this figure legend, the reader is referred to the web version of this article.).

Si forms a skeleton structure (shown in yellow) with holes where organic matter (shown in violet) can be embedded. It is possible that $\mathrm{Pb}$ also locates in the phytolith hole system. However, determination of the presence of $\mathrm{Pb}$ is beyond the resolution of the tomographic analysis. By wet digestion with aqua regia, the content of $\mathrm{Pb}$ in rice straw were found to be up to $118 \pm 37 \mathrm{mg} \mathrm{kg}^{-1}$ and more detailed chemical composition of the rice straw is provided in Appendix A.

Thermal treatment of the rice straw resulted in significant changes in morphology and chemical composition as shown in Fig. $1 \mathrm{~b}$ and Appendix B, respectively. With an increase in treatment temperature from $400{ }^{\circ} \mathrm{C}$ to $1000{ }^{\circ} \mathrm{C}$, a gradual decrease in organic matter content, from $4.93 \%$ to $0.38 \%$, was observed. Silica was also slagged and transformed, particularly at temperatures $>700{ }^{\circ} \mathrm{C}$, to more stable phases, such as cristobalite and tridymite, as revealed by XRD patterns (Fig. 1d), and changes in morphology of silica phases were shown in Fig. 1c. The removal of organic matter and changes in crystallinity of the silica phases could be the reason for a decrease in surface charge (Nguyen et al., 2014). When the treated temperature increased from $400{ }^{\circ} \mathrm{C}$ to $1000{ }^{\circ} \mathrm{C}$, surface charge gradually increased from -1.15 to $-0.29 \mu$ molc $\mathrm{g}^{-1}$. On heat-treatment, some $\mathrm{Pb}$ can be released or volatilized, while the remainder may be occluded within the slagged com- pounds, composed of glass and potentially crystallized silica phases. This is supported by data obtained from the PIXE method, which shows a change in total $\mathrm{Pb}$ content of the ash samples from 0.7 to $0.3 \mathrm{~g} \mathrm{~kg}^{-1}$ (Appendix B) when the treatment temperature increased from $400{ }^{\circ} \mathrm{C}$ to $1000{ }^{\circ} \mathrm{C}$. The PCA diagram (Fig. 1e) illustrated the differentiation between treatment temperature and chemical composition and release of $\mathrm{Si}$ and $\mathrm{Pb}$ in aqua regia solution. A close relation between $\mathrm{OC}$ and aqua regia-released $\mathrm{Pb}$ suggests the possible association of $\mathrm{Pb}$ with organic matter. No obvious correlation between aqua regia-released $\mathrm{Pb}$ and $\mathrm{Si}$ was confirmed.

\subsection{Solubility of phytPb in relation to thermal treatment}

Dissolution properties of phytolith, obtained from greenhouse- grown rice, in $\mathrm{DI}$ water, $\mathrm{H}_{2} \mathrm{O} 2$, aqua regia and $\mathrm{Na} 2 \mathrm{CO} 3$ are shown in Fig. 2.

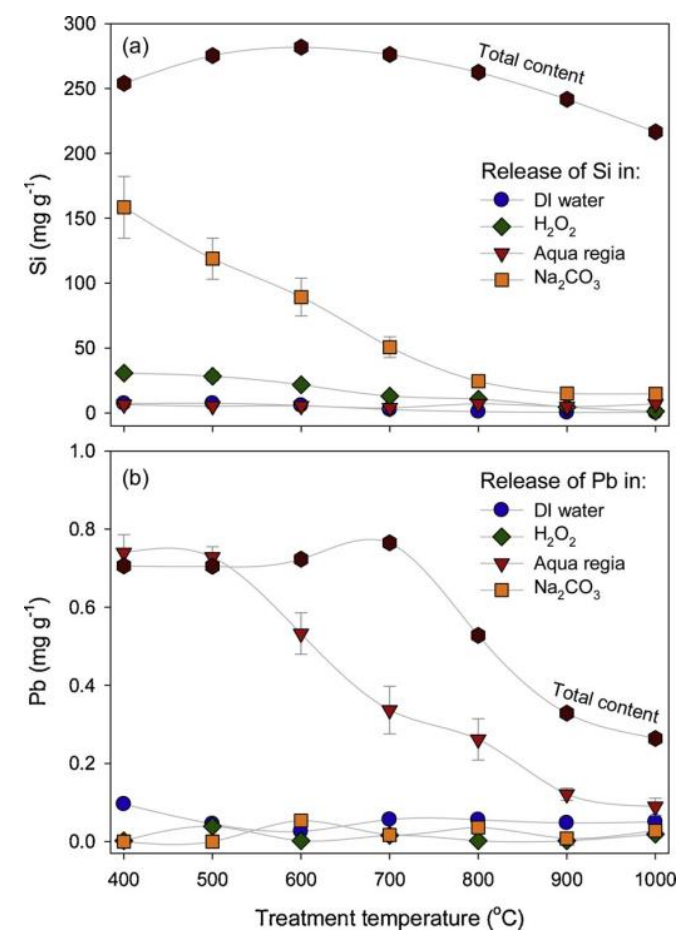

Fig. 2. Dissolution of thermally treated phytolith obtained from greenhouse- grown rice where (a) shows the concentration of $\mathrm{Si}$ released and $(\mathrm{b})$ shows the concentration of $\mathrm{Pb}$ released in $\mathrm{DI}$ water, $\mathrm{H} 2 \mathrm{O} 2$, aqua regia and $1 \% \mathrm{Na} 2 \mathrm{CO} 3$ solvents, as measured by ICP-OES. 
The soluble Si content in $\mathrm{H}_{2} \mathrm{O} 2$, DI water and $\mathrm{Na}_{2} \mathrm{CO} 3$, measured using ICP-OES, decreased from 37.7 to 1.2 $\mathrm{mg} \mathrm{g}^{-1}, 7.3$ to $0.4 \mathrm{mg} \mathrm{g}^{-1}$ and 158.5 to $14.7 \mathrm{mg} \mathrm{g}^{-1}$ respectively when the treatment temperature increased from 400 ${ }^{\circ} \mathrm{C}$ to $1000{ }^{\circ} \mathrm{C}$. No change was observed for dissolution in aqua regia after thermal treatment over the entire temperature range from $400{ }^{\circ} \mathrm{C}$ to $1000^{\circ} \mathrm{C}$, and the soluble Si content was maintained in the range from 3.9 to $7.0 \mathrm{mg} \mathrm{g}^{-1}$ (Fig. 2a). Different trends were observed for dissolution of $\mathrm{Pb}$ and results are presented in Fig. $2 \mathrm{~b}$. Soluble $\mathrm{Pb}$ content in the aqua regia solvent decreased from 0.74 to $0.09 \mathrm{mg} \mathrm{g}^{-1}$, while it was maintained at less than $0.1 \mathrm{mg} \mathrm{g}^{-1}$ in DI water, $\mathrm{H}_{2} \mathrm{O}_{2}$ and $\mathrm{Na}_{2} \mathrm{CO}_{3}$ solution following treatment over the entire temperature range from $400{ }^{\circ} \mathrm{C}$ to $1000^{\circ} \mathrm{C}$. At temperatures above $500^{\circ} \mathrm{C}$, lower contents of $\mathrm{Pb}$ were released when using aqua regia as solvent, which suggests that some $\mathrm{Pb}$ might be tightly entrapped in the phytolith structure and is not accessible by the aqua regia solvent Dissolution of phytolith silica has been reported as a control factor for the release of occluded substances (Nguyen et al., 2015; Tran et al., 2018; Trinh et al., 2017). However, no obvious evidence relating the release of Si and Pb was confirmed in this work. Among the extractants, aqua regia showed the best response for release of $\mathrm{Pb}$ compartmentalized in the phytolith structure.

\subsection{Soil phytolith and its relation to phytPb}

Fig. 3a presents images of phytoliths separated from the soil sam- ples, while the chemical content, obtained from EDS spectra, are shown in Fig. $3 \mathrm{~b}$ and the correlation of the contents of soil phytolith and phytPb are given in Fig. $3 \mathrm{c}$.
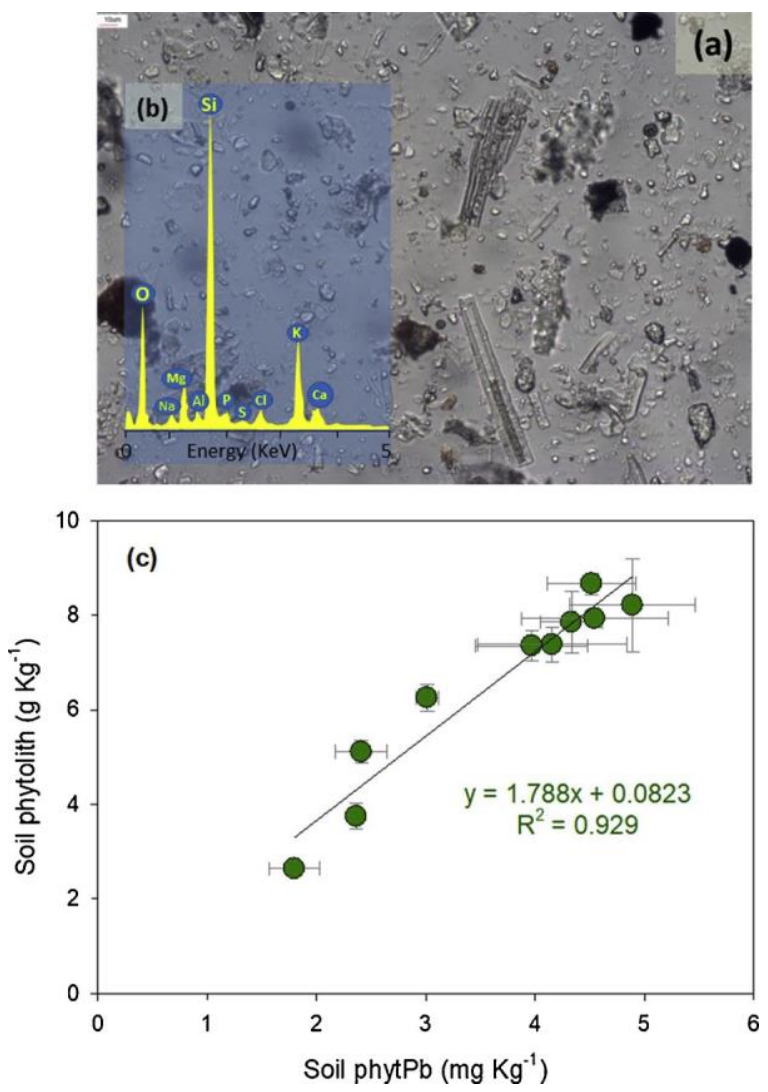

Fig. 3. Phytolith fragments separated from soil samples where (a) shows the images obtained using microscopy and (b) shows the chemical composition using EDS spectra and (c) shows the relationship between soil phytolith and phytPb.

Phytoliths separated from the soil samples showed various morphologies, including sticks and irregularly shaped plates, with a range of sizes up to $100 \mu \mathrm{m}$ (Fig. 3a). "Cellular" shapes were also observed, reflecting the plant origin of the phytoliths, and their sizes and smooth edges suggest an aging of the phytoliths (Alexandre et al., 2015; Corbineau et al., 2013). EDS spectra revealed the chemical composition of soil-aged phytoliths, in which $\mathrm{Si}, \mathrm{O}, \mathrm{K}, \mathrm{Ca}$ and $\mathrm{Mg}$ are the major elements (Fig. 3b). However, any Pb present in the soil-aged phytoliths was not detectable by the 
EDS method. Using aqua regia solution for extraction, it was found that the soil-aged phytoliths contained from 0.43 to $0.73 \mathrm{mg} \mathrm{g}^{-1}$. The phytPb contents in the soil ranged from 1.8 to $4.9 \mathrm{mg} \mathrm{kg}^{-1}$. We found a positive correlation between soil phytolith and phytPb $\left(\mathrm{R}^{2}=0.929, p<0.01\right)$ by plotting the contents of soil phytolith and phytPb (Fig. 3c).

\subsection{Fractionation and principal component analysis}

Fig. 4a describes the content of soil phytPb in comparison with other $\mathrm{Pb}$ fractions.
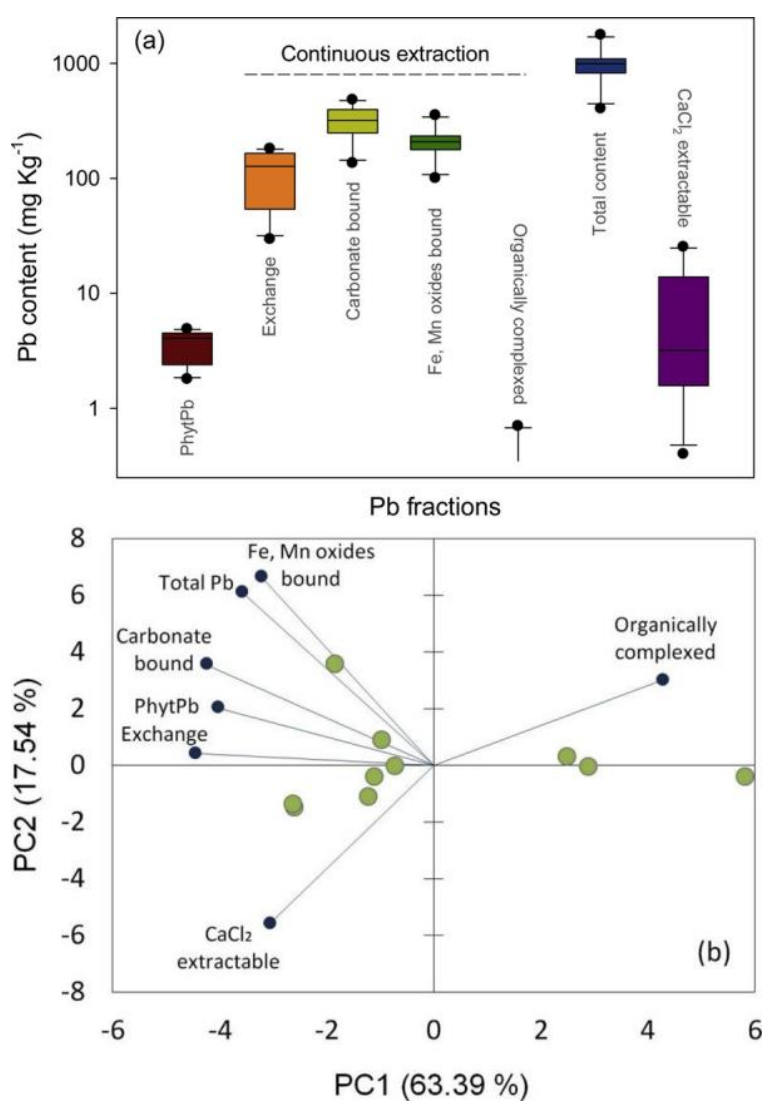

Fig. 4. Principal component analysis where (a) shows box plots representing the contents of Pb in soil-aged phytoliths and other fractions of the soil samples, and (b) shows score plots of PC1 versus PC2 indicating the differentiation of phytPb and other $\mathrm{Pb}$ forms in soil.

$\mathrm{Pb}$ was mostly found in the exchangeable fraction (114.4 $\left.\pm 53.3 \mathrm{mg} \mathrm{kg}^{-1}\right)$, the carbonate-bound fraction (317.0 $\left.\pm 95.9 \mathrm{mg} \mathrm{kg}^{-1}\right)$ and the Fe or Mn oxide-bound fractions (210.5 $\left.\pm 60.6 \mathrm{mg} \mathrm{kg}^{-1}\right)$, while a relatively low content of $\mathrm{Pb}$ was found to be associated with organic matter $\left(0.3 \pm 0.2 \mathrm{mg} \mathrm{kg}^{-1}\right)$. The amount of released $\mathrm{Pb}$ following sequential extraction decreases in the order: carbonate-bound $>$ Fe or Mn oxide-bound $>$ exchangeable >> organically-complexed.

The results after single extractions with $0.01 \mathrm{M} \mathrm{CaCl} 2$ showed relatively low levels of $\mathrm{Pb}$ released from soil samples $\left(0.4-25.3 \mathrm{mg} \mathrm{kg}^{-1}\right)$ which are only $\sim 1.7 \%$ in comparison with "mobile" fractions, such as the exchangeable or carbonatebound fractions. Compared to other fractions, the soil phytPb contents are quite similar to the organically-complexed $\mathrm{Pb}$ and $\mathrm{Pb}$ released by $\mathrm{CaCl}_{2}$ extraction, while they are about one or two orders of magnitude lower than carbonatebound and Fe or Mn oxide-bound forms.

Principal Component Analysis (PCA) was performed and PC1 versus PC2 represents the differentiation between phytPb and other soil $\mathrm{Pb}$ fractions, including exchangeable, $\mathrm{Fe}$ or $\mathrm{Mn}$ oxide-bound, organically- bound, $\mathrm{CaCl} 2-$ extractable and total content (Fig. 4b). The first PC showed negative values for all Pb fractions except the organicallycomplexed form. The second PC was strongly associated with the Fe or Mn oxide-bound form and the total content 
with a positive effect and the $\mathrm{CaCl}_{2}$-extractable form with a negative effect, while lesser correlations were found for exchangeable, phytPb and carbonate-bound forms. According to the ordination of variables in the PCA diagrams, phytPb tends to associate with the exchangeable and carbonate-bound fractions rather than other soil $\mathrm{Pb}$ fractions. Pearson coefficients, that pair the phytPb content with each $\mathrm{Pb}$ fraction, are shown in Appendix $\mathrm{E}$, and confirm their positive correlations $(P<0.05)$.

\section{Discussion}

\subsection{PhytPb in rice}

A content of $\mathrm{Pb}$ exceeding $118 \mathrm{mg} \mathrm{kg}^{-1}$ dry matter of rice straw is considered to be indicative of a sink of $\mathrm{Pb}$ in the rice straw. This sink provides a source of $\mathrm{Pb}$, which may be potentially toxic to humans (Fujimori et al., 2016), since it is a common fodder for cows and buffaloes and can enter the food chain. In the study area $\sim 12$ ton ha $^{-1}$ year $^{-1}$ straw is annually recycled to soil, and can transfer $\sim 1.4 \mathrm{~kg} \mathrm{~Pb} \mathrm{ha}^{-1}$. The availability of this Pb source is likely to be dependent on various treatment practices, such as thermal treatment of the rice straw, and can affect the phytolith, which is a carrier of $\mathrm{Pb}$ in soil. $\mathrm{Pb}$ absorbed from soil solution can be transported and located in different parts of the plant, e.g. root, stem and leaf (Udousoro et al., 2013). From the tomographic image obtained from a dried leaf of a rice plant (Fig. 1a), it is likely that most of the Pb locates in the compartmentalized spaces (holes) in the phytolith structure. Here, $\mathrm{Pb}$ can associate with the organic phase within the holes, or possibly bind to the cellular wall by forming $\mathrm{Pb}-\mathrm{C}$ bonds, in a similar way to $\mathrm{Si}$, which forms $\mathrm{Si}-\mathrm{C}$ bonds as described by Pan et al. (2017). These processes can be affected strongly by thermal treatment such as burning in field conditions.

The results obtained from PIXE analysis revealed that the total content of $\mathrm{Pb}$ in the ash samples remained at $0.7 \mathrm{~g}$ $\mathrm{kg}^{-1}$, in the temperature range up to $600-700{ }^{\circ} \mathrm{C}$ and decreased to $0.3 \mathrm{~g} \mathrm{~kg}^{-1}$ when the treated temperature increased to $1000^{\circ} \mathrm{C}$, indicating marked loss of $\mathrm{Pb}$ at higher temperatures. Generally, thermal treatments gradually removed the organic phase and resulted in part or complete destruction of the phytolith and formation of new crytalline phases (Nguyen et al., 2015). Consequently, some parts of Pb in rice straw could be released. However, observations in the batch experiments showed very low concentrations of water-soluble $\mathrm{Pb}(0.54 \pm 0.19 \mathrm{mg} 100$ $\mathrm{mg}^{-1}$ ) in burned products from treatment at $500-1000{ }^{\circ} \mathrm{C}$ (Fig. 2b) and this indicates that most of the $\mathrm{Pb}$ was still associated with or occluded within the phytolith (phytPb). Another possibility is that some parts of $\mathrm{Pb}$, after release, were re-adsorbed onto the surface of the ash solids. The surface charge of the ash phytolith ranged from - 0.29 to $1.15 \mu \mathrm{molC}^{-1}$ (more details in Appendix $\mathrm{B}$ ) indicating that the surface can serve as a reactive site for adsorption of cations such as $\mathrm{Pb}^{2+}$ (Nguyen et al., 2009b; Sposito et al., 1999). However, loading of Pb onto the phytolith surface and its consequent effects on phytolith dissolution was not investigated in this study. Digestion with aqua regia solution can partially reveal the phytPb pool and its potential release. A decrease in the concentration of aqua regiasoluble $\mathrm{Pb}$ with an increase in temperature during thermal treatment (Fig. 2b) might result from: 1 ) less $\mathrm{Pb}$ remaining in the sample after thermal treatment due to volatilization process and 2) stabilization of $\mathrm{Pb}$ by formation of more stable phases or encapsulation into the phytolith structure. During thermal treatment, phytPb phases can be transformed to $\mathrm{PbO}$, which is a non- volatile form (Wang et al., 2016). The presence of $\mathrm{Cl}(\sim 0.32 \%$ in original rice straw measured by PIXE method and given in Appendix B) may facilitate the formation of $\mathrm{PbCl} 2$ which is volatile (Rio et al., 2007; Wang et al., 2016; Yoo et al., 2005). Wang et al. (2016) reported that the presence of SiO2 and Al2O3 can lower the chlorination and volatilization temperature of $\mathrm{Pb}$. A close relationship between $\mathrm{Pb}$ and $\mathrm{Cl}$, confirmed by $\mathrm{PCA}$ (Fig. 1d), suggests possible co-volatilization. This may, therefore, be another reason for the observed loss of $\mathrm{Pb}$ from the phytolith structures.

Along with decreases in the content of phytPb at high temperatures, a remarkable reduction in the solubility of phytPb was also observed (Fig. 2b). This may be due to the association of phytPb with other available substances, such as Al, leading to formation of PbAl2O4 which can also immobilize the phytPb (Wang et al., 2016; Yu et al., 2013). The reduced solubility of phytPb may also relate to the encapsulation of phytPb into silica phases. Increasing the treatment temperature (e.g. $>700^{\circ} \mathrm{C}$ ) can result in slagging (Fig. 1d) and crystallization of amorphous silica to more stable forms, such as cristobalite and tridymite, as deduced from XRD patterns, which can affect Pb encapsulation. 


\subsection{PhytPb in soil}

After harvesting rice straw is returned to the field, and in this way an amount of phytolith of $\sim 0.72$ ton ha ${ }^{-1}$ can annually be recycled to soil. Despite the fact that soil samples were taken at the end of cropping season, when the area has not been fed from such rice residues, remarkable values for soil phytolith content were still observed. The content of soil-aged phytolith found in the 10 fields ranged from 2.6 to $8.7 \mathrm{~g} \mathrm{~kg}^{-1}$ (7.8 to 26.1 ton ha ${ }^{-1}$, calculated for the top layer of $0-20 \mathrm{~cm}$ of soil, and bulk density of $1.5 \mathrm{~g} \mathrm{~cm}^{-3}$ ). This is significantly higher than the value for the annual recycle phytolith from rice straw, implying that the current phytolith pool is a consequence of long-term accumulation. This is in agreement with another observation for paddy soils by Wickramasinghe and Rowell (2006). It can be deduced that the accumulation of phytoliths might serve as a new sink of $\mathrm{Pb}$ in soil. The phytPb was found to range from 0.43 to $0.73 \mathrm{mg} \mathrm{g}^{-1}$ in the soil aged phytolith and from 12.9 to $21.9 \mathrm{~kg} \mathrm{ha}^{-1}$ in the study soil. While the $\mathrm{Si} / \mathrm{Pb}$ ratio of the rice straw is 349 , the $\mathrm{Si} / \mathrm{Pb}$ ratio of the soil-aged phy- tolith range from $\sim 177$ to $\sim 688$. The difference in these $\mathrm{Si} / \mathrm{Pb}$ ratios indicates that $\mathrm{Pb}$ and $\mathrm{Si}$ might be lost at different rates. Herein we found a positive correlation between the contents of soil phytolith and soil phytPb (Fig. 3c), confirming the role of soil phytolith as a source of $\mathrm{Pb}$. From the results of soil phytPb relative to other soil $\mathrm{Pb}$ fractions (Fig. $4 \mathrm{a}$ ), it was confirmed that the phyt $\mathrm{Pb}$ has a limited contribution to the whole soil $\mathrm{Pb}$ pool. This also means that most of the $\mathrm{Pb}$ loaded by the ricestraw phytolith has been lost or transferred to other Pb frac- tions in the soil. In the PCA diagram (Fig. 4b), it is revealed that phytPb tends to associate with carbonate-bound and exchange fractions. However, the obtained data was not capable of providing detailed in- formation about the association between them. It suggests that more work targeting phyt $\mathrm{Pb}$ and its relation to other soil $\mathrm{Pb}$ fractions is needed.

\section{Conclusion}

This work is primarily concerned with $\mathrm{Pb}$ associated with phytolith in rice straw and its transformation upon thermal treatment. A decline in $\mathrm{Pb}$ content in the rice straw ash samples along with increasing treatment temperature was assigned to loss of $\mathrm{Pb}$ via volatilization, which might be a health risk when burning Pb-tainted rice straw. A twostep procedure, separating phytoliths from the soil and extracting $\mathrm{Pb}$ from the separated phytoliths, allowed determination of the phytPb pool in the soil. We observed a positive correlation between soil phy- tolith content and soil phytPb, suggesting phytPb as an overlooked threathen to the $\mathrm{Pb}$ secondary pollution once phytolith was dissolved. Our work also suggests a necessity of new incentives to moderate the phytPb pathway transport accompanying the phytolith cycle and to seek other advanced recycling techniques for mitigation of phytPb impacts.

\section{Acknowledgements}

X-ray-tomographic microscopy was performed with skilful help by the TOMCAT group at the Paul Scherrer Institute, Villigen, Switzerland. Great help from Sarah B. Cichy for morphological characterization of phytoliths from the tomographic dataset is acknowledged 
Appendix A. A comparison of chemical composition of the rice straw and soil aged phytolith at the same sampling site (S1)

\begin{tabular}{lccccccccccccc}
\hline Sample & $\mathrm{Si}$ & $\mathrm{Al}$ & $\mathrm{Ca}$ & $\mathrm{Mg}$ & $\mathrm{P}$ & $\mathrm{S}$ & $\mathrm{Cl}$ & $\mathrm{K}$ & $\mathrm{Na}$ & $\mathrm{Al}$ & $\mathrm{Pb}$ & LOI \\
\hline $\begin{array}{l}\text { Soil aged } \\
\text { phytolith }\end{array}$ & 20.9 & 0.61 & 1.94 & 0.94 & 1.05 & 1.33 & 4.41 & 10.1 & 2.07 & 0.61 & 533 & n.a. \\
\hline
\end{tabular}

LOI: loss of ignition; n.a.: not analyzed 
Appendix B. Organic carbon, surface charge, aqua regia-extractable $\mathrm{Si}$ and $\mathrm{Pb}$, and chemical composition of the ash samples analysed by PIXE method ( $n=3$, mean values with standard deviations in brackets; other data obtained from single analysis)

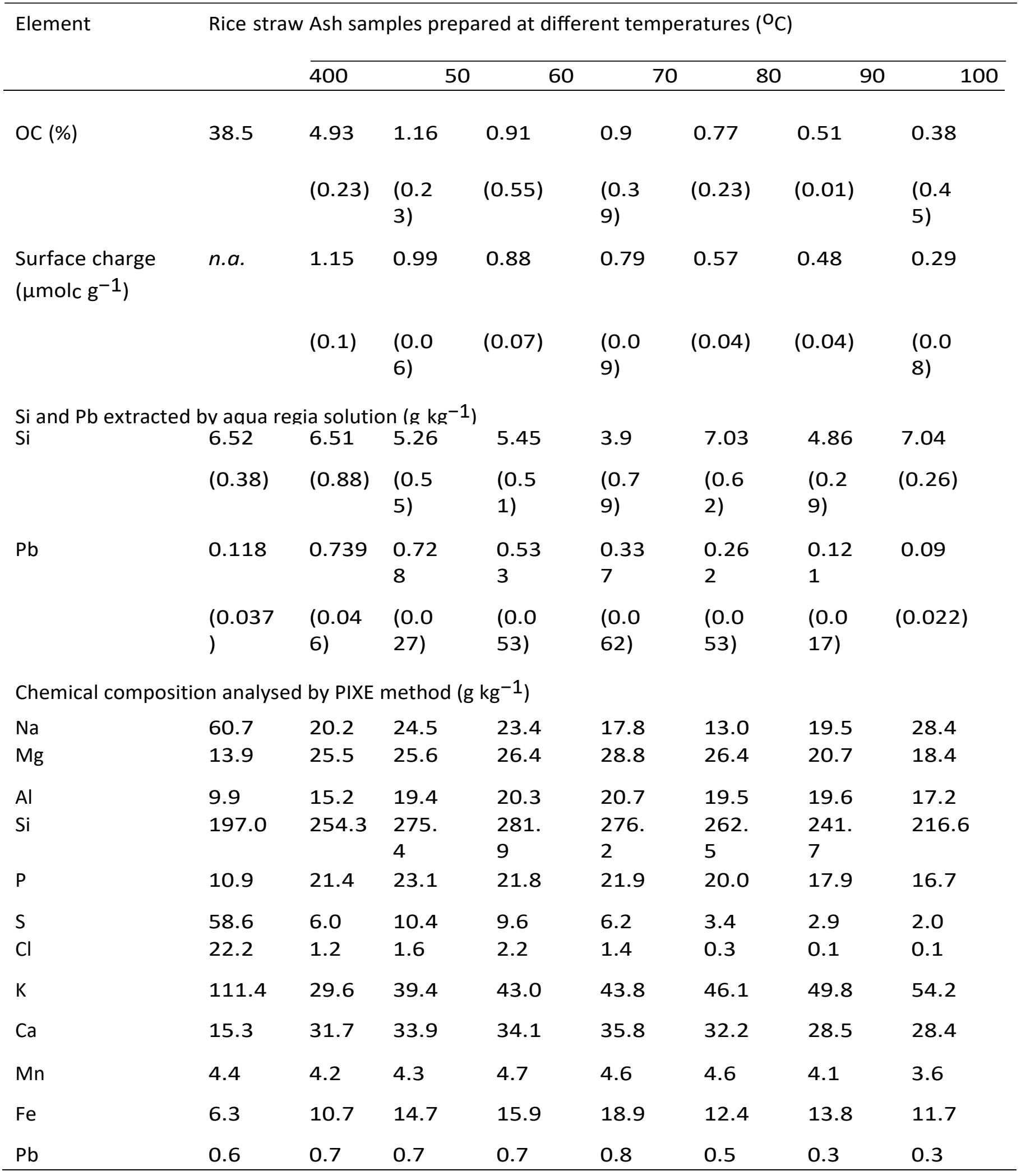

n.a.: not analyzed. 


\begin{tabular}{|c|c|c|c|c|c|c|c|c|c|c|}
\hline $\begin{array}{l}\text { Element (mg } \\
\mathrm{kg}^{-1} \text { ) }\end{array}$ & $\begin{array}{l}\text { Sampl } \\
\text { es }\end{array}$ & & & & & & & & & \\
\hline $\mathrm{Mg}$ & 3853 & 4022 & 3711 & 4000 & 4211 & 4049 & 4302 & 4036 & 4316 & 442 \\
\hline \multirow[t]{2}{*}{ Al } & 45766 & 4823 & 4836 & 5178 & 5335 & 5048 & 5252 & 4986 & 5199 & $\begin{array}{l}1 \\
528\end{array}$ \\
\hline & & 4 & 3 & 1 & 6 & 7 & 9 & 7 & 1 & 82 \\
\hline \multirow[t]{2}{*}{$\mathrm{Si}$} & 11805 & 1237 & 1169 & 1253 & 1252 & 1266 & 1236 & 1158 & 1280 & 129 \\
\hline & 3 & 87 & 34 & 58 & 80 & 81 & 32 & 44 & 89 & 117 \\
\hline$P$ & 132.5 & 116.2 & 67.81 & 48.17 & 143.2 & 166.4 & 207.1 & 94.25 & 153.3 & $\begin{array}{l}40.3 \\
7\end{array}$ \\
\hline$S$ & 4362 & 3409 & 4805 & 5531 & 7564 & 5816 & 5062 & 4811 & 4335 & $\begin{array}{l}352 \\
4\end{array}$ \\
\hline $\mathrm{Cl}$ & 57.46 & 37.65 & 48.66 & 41.02 & 73.88 & 126.2 & 96.74 & 108.1 & 74.11 & $\begin{array}{l}39.6 \\
5\end{array}$ \\
\hline K & 9328 & 9980 & $\begin{array}{l}1008 \\
6\end{array}$ & $\begin{array}{l}1088 \\
0\end{array}$ & $\begin{array}{l}1094 \\
3\end{array}$ & $\begin{array}{l}1031 \\
9\end{array}$ & $\begin{array}{l}1082 \\
8\end{array}$ & $\begin{array}{l}1052 \\
0\end{array}$ & $\begin{array}{l}1060 \\
8\end{array}$ & $\begin{array}{l}107 \\
90\end{array}$ \\
\hline $\mathrm{Ca}$ & 5854 & 4727 & 6073 & 7280 & 9578 & 7475 & 7148 & 7019 & 5998 & $\begin{array}{l}514 \\
0\end{array}$ \\
\hline $\mathrm{Mn}$ & 152.8 & 116.8 & 19.99 & 44.56 & 130.4 & 71.71 & 82.58 & 85.66 & 156.2 & $\begin{array}{l}133 . \\
3\end{array}$ \\
\hline \multirow[t]{2}{*}{$\mathrm{Fe}$} & 29572 & 2725 & 2583 & 2771 & 3410 & 2546 & 3079 & 2828 & 2712 & 370 \\
\hline & & 8 & 7 & 9 & 9 & 7 & 0 & 3 & 9 & 41 \\
\hline $\mathrm{Pb}$ & 1116 & 921.3 & 1014 & 1090 & 1766 & 971.5 & 816.4 & 827.4 & 1064 & 403. \\
\hline
\end{tabular}


Appendix $\mathrm{D}$. Contents of aged phytoliths and their phytPb in the soil samples, other soil $\mathrm{Pb}$ fractions and physio-chemical properties ( $n=3$, mean values with standard deviations in brackets; other data obtained from single analysis)

Soil

samples

\begin{tabular}{|c|c|c|c|c|c|c|c|c|c|c|}
\hline \multirow[t]{2}{*}{ Phytolith $\left(\mathrm{g} \mathrm{kg}^{-1}\right)$} & 6.3 & 7.4 & 8.7 & 7.9 & 7.9 & 8.2 & 3.7 & 5.1 & 7.4 & 2.6 \\
\hline & $(0.3)$ & $(0.3)$ & $(0.2)$ & $(0.6)$ & $(0.2)$ & $(1.0)$ & $(0.3)$ & $(0.2)$ & $(0.4)$ & $\begin{array}{l}(0 . \\
1)\end{array}$ \\
\hline \multirow[t]{2}{*}{ PhytPb (mg kg $\left.{ }^{-\perp}\right)$} & 3.0 & 4.0 & 4.5 & 4.3 & 4.5 & 4.9 & 2.4 & 2.4 & 4.2 & 1.8 \\
\hline & (0.1) & $(0.5)$ & $(0.4)$ & $(0.3)$ & $(0.7)$ & $(0.6)$ & (0.1) & $(0.2)$ & $(0.7)$ & $\begin{array}{l}\text { (0. } \\
2)\end{array}$ \\
\hline
\end{tabular}

Other $\mathrm{Pb}$ fractions

$\left(\mathrm{mg} \mathrm{kg}^{-1}\right)$

Exchange

$\begin{array}{llllllllll}166.9 & 154.0 & 180.6 & 153.4 & 164.6 & 87.4 & 50.7 & 55.0 & 101.3 & 29 .\end{array}$

Carbonate bound

$\begin{array}{llll}166.9 & 154.0 & 180.6 & 153.4 \\ 164.6 & 87.4 & 50.7 & 55.0\end{array}$

Fe, Mn oxides

419.5

$337.5 \quad 351.1 \quad 388.0$

$\begin{array}{llllll}481.4 & 279.8 & 216.6 & 259.2 & 300.8 & 136\end{array}$

bound

$233.4 \quad 178.8 \quad 190.5 \quad 234.0 \quad 353.6$

223.3

Organically

$\begin{array}{lll}0.02 & 0.02 \quad 0.02\end{array}$

0.12

$0.31 \quad 0.02$

0.26

0.47

0.08

0.7

complexed

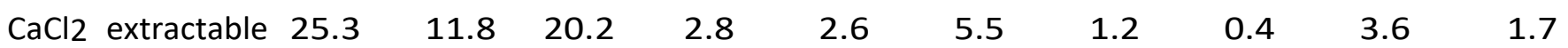

Total content

$\begin{array}{lllll}1116 & 921 & 1014 & 1090 & 1766\end{array}$

972816

$827 \quad 1064$

404

Physio-chemical

$\begin{array}{lllllllllllll}\mathrm{pHKCl} & 3.4 & 3.59 & 3.41 & 3.9 & 4.14 & 3.92 & 4.65 & 4.59 & 3.69 & 5.2 \\ & (0.01 & (0.01 & (0.01 & (0.01 & (0.01 & (0.01 & (0.02 & (0.01 & (0.01 & (0.0 \\ & 1 & ) & ) & ) & ) & ) & ) & ) & ) & 3) \\ \text { OC (\%) } & 2.44 & 2.24 & 2.39 & 2.09 & 1.89 & 2.9 & 2.04 & 2.12 & 2.6 & 1.33 \\ & (0.02 & (0.02 & (0.05 & (0.02 & (0.02 & (0.05 & (0.02 & (0.02 & (0.05 & (0.0 \\ & & & ) & ) & ) & ) & ) & ) & ) & ) & 4)\end{array}$

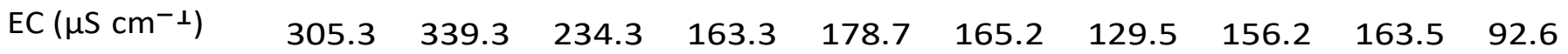

(b.3) (9.1) $\quad f^{11.1} \quad(2.3) \quad f^{11.3} \quad(4.1) \quad(4.9) \quad(4.2) \quad(4.2) \quad(2.2)$ 
Appendix E. Correlation coefficients (Pearson's test) of the phytPb content and other soil Pb fractions

\begin{tabular}{|c|c|c|c|c|c|c|c|}
\hline & $\begin{array}{l}\text { PhytP } \\
\text { b }\end{array}$ & $\begin{array}{l}\text { Exchan } \\
\text { ge }\end{array}$ & $\begin{array}{l}\text { Carbonate } \\
\text { bound }\end{array}$ & $\begin{array}{l}\text { Fe, Mn oxides } \\
\text { bound }\end{array}$ & $\begin{array}{l}\text { Organically } \\
\text { complexed }\end{array}$ & $\begin{array}{l}\mathrm{CaCl} 2 \\
\text { extractable }\end{array}$ & $\begin{array}{l}\text { Total } \\
\text { content }\end{array}$ \\
\hline PhytPb & 1 & $\begin{array}{l}0.641 \\
*\end{array}$ & $0.662^{*}$ & 0.488 & $-0.680^{*}$ & $0.721^{*}$ & 0.514 \\
\hline Exchange & & 1 & 0.897 & 0.576 & -0.730 & 0.665 & 0.689 \\
\hline $\begin{array}{l}\text { Carbonate } \\
\text { bound }\end{array}$ & & & 1 & 0.857 & -0.587 & 0.433 & Q.904 \\
\hline $\begin{array}{l}\text { Fe, Mn oxides } \\
\text { bound }\end{array}$ & & & & 1 & -0.339 & 0.02 & \$.978 \\
\hline $\begin{array}{l}\text { Organically } \\
\text { complexed }\end{array}$ & & & & & 1 & -0.616 & -0.416 \\
\hline $\begin{array}{l}\mathrm{CaCl} 2 \\
\text { extractable }\end{array}$ & & & & & & 1 & 0.126 \\
\hline Total content & & & & & & & 1 \\
\hline
\end{tabular}

*Correlation is significant at the 0.05 level (2-tailed).

** Correlation is significant at the 0.01 level (2-tailed). 


\section{References}

Alexandre, A., Meunier, J.D., Colin, F., Koud, J.M., 1997. Plant impact on the biogeo- chemical cycle of silicon and related weathering processes. Geochim. Cosmochim. Acta 61, 677-682.

Alexandre, A., Basile-Doelsch, I., Delhaye, T., Borshneck, D., Mazur, J.C., Reyerson, P., Santos, G.M., 2015. New highlights of phytolith structure and occluded carbon lo- cation: 3-D X-ray microscopy and NanoSIMS results. Biogeosciences 12, 863-873.

Angeli, F., Jollivet, P., Charpentier, T., Fournier, M., Gin, S., 2016. Structure and chemical durability of lead crystal glass. Environ. Sci. Technol. 50, 11549-11558.

Botha, T., 2013. A tale of two neglected systems-structure and function of the thin- and thick-walled sieve tubes in monocotyledonous leaves. Front. Plant. Sci. 4, 297.

Corbineau, R., Reyerson, P.E., Alexandre, A., Santos, G.M., 2013. Towards producing pure phytolith concentrates from plants that are suitable for carbon isotopic analysis. Rev. Palaeobot. Palynol. 197, 179-185.

Dove, P.M., Crerar, D.A., 1990. Kinetics of quartz dissolution in electrolyte solutions using a hydrothermal mixed flow reactor. Geochim. Cosmochim. Acta 54, 955-969.

Fakhri, Y., Bjørklund, G., Bandpei, A.M., Chirumbolo, S., Keramati, H., Hosseini Pouya, R., Asadi, A., Amanidaz, N., Sarafraz, M., Sheikhmohammad, A., Alipour, M., Baninameh, Z., Mohseni, S.M., Sarkhosh, M., Ghasemi, S.M., 2018. Concentrations of arsenic and lead in rice (Oryza sativa L.) in Iran: A systematic review and carcinogenic risk assessment. Food Chem. Toxicol. 113, 267-277.

Fu, J., Zhou, Q., Liu, J., Liu, W., Wang, T., Zhang, Q., Jiang, G., 2008. High levels of heavy metals in rice (Oryza Sativa L.) from a typical E-waste recycling area in southeast China and its potential risk to human health. Chemosphere 71, 1269-1275.

Fujimori, T., Eguchi, A., Agusa, T., Tue, N.M., Suzuki, G., Takahashi, S., Viet, P.H., Tanabe, S., Takigami, H., 2016. Lead contamination in surface soil on roads from used lead-acid battery recycling in Dong Mai, Northern Vietnam. J. Mater. Cycles Waste 18, 599-607.

Guo, F., Song, Z., Sullivan, L., Wang, H., Liu, X., Wang, X., Li, Z., Zhao, Y., 2015. Enhancing phytolith carbon sequestration in rice ecosystems through basalt powder amendment. Sci. Bull. 60, 591-597.

Haynes, R.J., 2014. A contemporary overview of silicon availability in agricultural soils. J. Plant Nutr. Soil. Sci. 177 (6), 831-844. 
ISO 11466, 1995. Soil Quality: Extraction of Trace Elements Soluble in Aqua Regia. International Organization for Standardization, Geneva.

Klotzbücher, T., Marxen, A., Vetterlein, D., Schneiker, J., Türke, M., van Sinh, N., Manh, N.H., van Chien, H., Marquez, L., Villareal, S., Bustamante, J.V., Jahn, R., 2016. Plant-available silicon in paddy soils as a key factor for sustainable rice production in Southeast Asia. Basic. Appl. Ecol. 16 (8), 665-673.

Koedrith, P., Seo, Y.R., 2011. Advances in carcinogenic metal toxicity and potential molecular markers. Int. J. Mol. Sci. 12, 9576-9595.

Kögel-Knabner, I., Amelung, W., Cao, Z., Fiedler, S., Frenzel, P., Jahn, R., Kalbitz, K., Kölbl, A., Schloter, M., 2010. Biogeochemistry of paddy soils. Geoderma 157, 1-14.

Li, Z., Song, Z., Parr, J.F., Wang, H., 2013. Occluded C in rice phytoliths: implications to biogeochemical carbon sequestration. Plant Soil. 370, 615-623.

Li, J., Dong, F., Lu, Y., Yan, Q., Shim, H., 2014a. Mechanisms controlling arsenic uptake in rice grown in mining impacted regions in South China. PLoS One 9, e108300.

Li, Z., Song, Z., Cornelis, J.T., 2014b. Impact of rice cultivar and organ on elemental composition of phytoliths and the release of bio-available silicon. Front. Plant. Sci. 5, 529.

Liu, J., Ma, X., Wang, M., Sun, X., 2013. Genotypic differences among rice cultivars in lead accumulation and translocation and the relation with grain Pb levels. Ecotox. Environ. Safe. 90, 35-40.

Loucaides, S., Behrends, T., Van Cappellen, P., 2010. Reactivity of biogenic silica: surface versus bulk charge density. Geochim. Cosmochim. Acta 74, 517-530.

Meunier, J.D., Keller, C., Guntzer, F., Riotte, J., Braun, J.J., Anupama, K., 2014. Assessment of the 1\% $\mathrm{Na2CO} 3$ technique to quantify the phytolith pool. Geoderma $216,30-35$.

Mohamad Remli, N.A., Md Shah, U.K., Mohamad, R., Abd-Aziz, S., 2014. Effects of chemical and thermal pretreatments on the enzymatic saccharification of rice straw for sugars production. BioRes. 9, 510522.

Nguyen, N.M., Dultz, S., Kasbohm, J., 2009a. Simulation of retention and transport of copper, lead and zinc in a paddy soil of the Red River Delta, Vietnam. Agric. Ecosyst. Environ. 129, 8-16.

Nguyen, N.M., Dultz, S., Kasbohm, J., Le, D., 2009b. Clay dispersion and its relation to surface charge in a paddy soil of the Red River Delta, Vietnam. J. Plant. Nutr. Soil. Sci. 172, 477-486. 
Nguyen, N.M., Dultz, S., Guggenberger, G., 2014. Effects of pretreatment and solution chemistry on solubility of rice-straw phytoliths. J. Plant. Nutr. Soil. Sci. 177, 349-359.

Nguyen, N.M., Dultz, S., Picardal, F., Bui, T.K.A., Pham, Q.V., Schieber, J., 2015. Release of potassium accompanying the dissolution of rice straw phytolith. Chemosphere 119, 371-376.

Nguyen, M.N., Dultz, S., Picardal, F., Bui, A.T.K., Pham, Q.V., Dam, T.T.N., Nguyen, C.X., Nguyen, N.T., Bui, H.T., 2016. Simulation of silicon leaching from flooded rice paddy soils in the Red River Delta, Vietnam. Chemosphere 145, 450-456.

Nutescu, E.A., Burnett, A., Fanikos, J., Spinler, S., Wittkowsky, A., 2016. Erratum to: pharmacology of anticoagulants used in the treatment of venous thromboembolism. J. Thromb. Thrombolys. 42, 296311.

Pan, M., Gan, X., Mei, C., Liang, Y., 2017. Structural analysis and transformation of biosilica during lignocellulose fractionation of rice straw. J. Mol. Struct. 1127, 575-582.

Parr, J.F., Sullivan, L.A., 2005. Soil carbon sequestration in phytoliths. Soil. Biol. Biochem. 37, 117-124.

Qi, L., Li, F.Y., Huang, Z., Jiang, P., Baoyin, T., Wang, H., 2017. Phytolith-occluded or-ganic carbon as a mechanism for long-term carbon sequestration in a typical steppe: the predominant role of belowground productivity. Sci. Total. Environ. 577, 413-417.

Rio, S., Verwilghen, C., Ramaroson, J., Nzihou, A., Sharrock, P., 2007. Heavy metal va-porization and abatement during thermal treatment of modified wastes. J. Hazard. Mater. 148, 521-528.

Ru, N., Yang, X., Song, Z., Liu, H., Hao, Q., Liu, X., Wu, X., 2018. Phytoliths and phytolith carbon occlusion in aboveground vegetation of sandy grasslands in eastern Inner Mongolia, China. Sci. Total Environ. 625, 1283-1289.

Sommer, M., Jochheim, H., Höhn, A., Breuer, J., Zagorski, Z., Busse, J., Barkusky, D., Meier, K., Puppe, D., Wanner, M., Kaczorek, D., 2013. Si cycling in a forest biogeo- system: the importance of transient state biogenic Si pools. Biogeosciences 10, 4991-5007.

Song, A., Ning, D., Fan, F., Li, Z., Provance-Bowley, M., Liang, Y., 2015. The potential for carbon bio-sequestration in China's paddy rice (Oryza sativa L.) as impacted by slag- based silicate fertilizer. Sci. Rep. 5, 17354.

Song, Z., McGrouther, K., Wang, H., 2016. Occurrence, turnover and carbon sequestration potential of phytoliths in terrestrial ecosystems. Earth Sci. Rev. 158, 19-30. 
Sposito, G., Skipper, N.T., Sutton, R., Park, S.H., Soper, A.K., Greathouse, J.A., 1999. Surface geochemistry of the clay minerals. Proc. Natl. Acad. Sci. USA. 96, 3358-3364.

Tessier, A., Campbell, P.G.C., Bisson, M., 1979. Sequential extraction procedure for the speciation of particulate trace metals. Anal. Chem. 51, 844-851.

Tran, C.T., Mai, N.T., Nguyen, V.T., Nguyen, H.X., Meharg, A., Carey, M., Dultz, S., Marone, F., Cichy, S.B., Nguyen, M.N., Aitkenhead, M., 2018. Phytolith-associated potassium in fern: characterization, dissolution properties and implications for slash-and-burn agriculture. Soil Use Manage. 34, 28-36.

Trinh, T.K., Nguyen, T.T.H., Nguyen, T.N., Wu, T.Y., Meharg, A.A., Nguyen, M.N., 2017. Characterization and dissolution properties of phytolith occluded phosphorus in rice straw. Soil Tillage Res. 171, 19-24.

Udousoro, I.I., Umoren, I., Udoh, A., 2013. Translocation and accumulation of trace metals in rice plants in Nsit Ubium, Akwa Ibom State of Nigeria. Geosystem Engineering 16, 129-138.

Uraguchi, S., Mori, S., Kuramata, M., Kawasaki, A., Arao, T., Ishikawa, S., 2009. Root-to- shoot Cd translocation via the xylem is the major process determining shoot and grain cadmium accumulation in rice. J. Exp. Bot. 60 (2677), 2688

Walther, J.V., 1996. Relation between rates of aluminosilicate mineral dissolution, $\mathrm{pH}$, temperature, and surface charge. Am. J. Sci. 296, 693-728.

Wang, J., Wang, X., Xu, M., Feng, G., Zhang, W., Lu, Ca., 2015. Crop yield and soil organic matter after long-term straw return to soil in China. Nutr. Cycl. Agroecosys. 102, 371-381.

Wang, S.J., He, P.J., Xia, Y., Lu, W.T., Shao, L.M., Zhang, H., 2016. Role of sodium chloride and mineral matrixes in the chlorination and volatilization of lead during waste thermal treatment. Fuel Process. Technol. 143, 130-139.

Wasserman, G.A., Liu, X., Lolacono, N.J., Factor-Litvak, P., Kline, J.K., Popovac, D., Morina, N., Musabegovic, A., Vrenezi, N., Capuni-Paracka, S., Lekic, V., Preteni- Redjepi, E., Hadzialjevic, S., Slavkovich, V., Graziano, J.H., 1997. Lead exposure and intelligence in 7-year-old children: the Yugoslavia Prospective Study. Environ. Health Perspect. 105, 956-962.

Wickramasinghe, D.B., Rowell, D.L., 2006. The release of silicon from amorphous silica and rice straw in Sri Lankan soils. Biol. Fert. Soils 42, 231-240.

Yoo, J.M., Kim, B.S., Lee, J.C., Kim, M.S., Nam, C.W., 2005. Kinetics of the volatilization removal of lead in electric arc furnace dust. Mater. Trans. 46, 323-328. 
Yu, J., Sun, L., Xiang, J., Hu, S., Su, S., 2013. Kinetic vaporization of heavy metals during fluidized bed thermal treatment of municipal solid waste. Waste Manage. 33, 340-346.

Yu, H.-Y., Liu, C., Zhu, J., Li, F., Deng, D.-M., Wang, Q., Liu, C., 2016. Cadmium avail- ability in rice paddy fields from a mining area: The effects of soil properties high- lighting iron fractions and $\mathrm{pH}$ value. Environ. Pollut. $209,38-45$.

Zeng, F., Mao, Y., Cheng, W., Wu, F., Zhang, G., 2008. Genotypic and environmental variation in chromium, cadmium and lead concentrations in rice. Environ. Pollut. 153, 309-314 
